\title{
The Benefit of Adding Key Audit Matters to the Auditing Report
}

\author{
Hao Li \\ School of Economics and Management \\ Nanjing University of Science and Technology \\ Nanjing, China \\ lihao_alex@163.com
}

\begin{abstract}
On December 23rd, 2016, the Ministry of Finance issued a new audit guideline "No. 1504 Auditing Standards for Chinese Certified Public Accountants - Communicating Key Audit Matters in Auditing Report." Based on the audit report of $84 \mathrm{~A}+\mathrm{H}$-share listed companies in 2016, we investigated the cost and benefit of new key audit matters. The results we obtained demonstrate that the disclosure of additional information by Chinese auditors has very limited effects, comparing with the content and form of the key audit matters of foreign countries. Our empirical results do not support the idea that the disclosure of key audit matters brings significant benefits. Our findings indicate that the disclosure of additional information by the auditors rather has a symbolic value than an informative value. However, our studies allow enriching the current international debate on the introduction of key audit matters.
\end{abstract}

Keywords—key audit matters; benefit; audit quality; market reaction

\section{INTRODUCTION}

In order to meet the capital market demand for high-quality accounting information and improve the quality of audit reports of listed companies, the Ministry of Finance released a new audit standard on December 23rd, 2016-"No. 1504 Auditing Standards for Chinese Certified Public Accountants Communicating Key Audit Matters in Auditing Report." The new auditing standard requires the $\mathrm{A}+\mathrm{H}$ share companies to implement the new standard to their financial reporting audit from January 1st, 2017. These companies took the lead in implementing the new standard. So how to disclose the key audit matters in Chinese audit reports, and how to balance the benefits and costs brought about by the disclosure of key audit matters, are the focuses of this article.

Influenced by the audit failure of enterprises in various countries since the early 21st century and the financial crisis in 2008, the international calls for improving the audit quality and improving the information content of audit reports have been on the rise.

Regulators have begun the regulatory reform process in this area. From 2014 European Union pointed that audit report on financial reporting should specify the most significant risks of material misstatements and the CPA's measures [7]. The International Auditing and Assurance Standards Board (IAASB 2013) and the Public Company Accounting Oversight Board (PCAOB, 2013) recently proposed new auditing standards for public companies that require auditors to disclose specific audits of key auditing matters in their audit reports (Key Audit Matters, KAM). These changes in the audit report are aimed to reduce information asymmetry - the gap between the information the investors want to obtain from the audit report and the disclosure of the company and the audit report [4].

However, there is no evidence that requiring auditors to add additional information will increase the value of the audit report information and reduce the information asymmetry that exists between management and investors. Practitioners and academics challenge the addition of key audit matters to audit report, and they doubt that KAMs may become models over time (IAASB, 2012a). Due to reliability issues, auditors may report key issues as few as possible or provide lengthy disclosures (IAASB, 2012a). At the same time, the key issue segment uses accounting professional language, so the users of audit reports may find it is hard to understand as a nonaccounting professional [3]. As a result, the disclosure of key audit matters may result in excessive amounts of other reporting content, obscure audit reports, additional costs and uncertainties (IAASB, 2012a).

The remainder of this article is organized as follows. The second part introduces the content of the key audit matters segment guidelines and the specific analysis of the disclosure in 2017. The third part analyzes the expected costs and benefits of disclosing the key audit matters and makes assumptions. The fourth part builds the hypothesis model. The fifth part, carry on the analysis and discuss the data result. The last section summarizes the results and draws conclusions.

\section{NEW Auditing StandardS AND ExECUTIVE ANALYSIS}

\section{A. $\quad$ Proposed key audit matters}

In 2016, the Ministry of Finance issued 12 new auditing standards for financial reports. The only new one was "Auditing Standards for Chinese Certified Public Accountants Communicating Key Audit Matters in Auditing Report", which is the core of this revised standard. Meanwhile, the enforcement of No.1504 conforms to the trend of the revision for the global auditing report standards [6].

"Key Audit Matter refers to the matter that certified public accountants consider to be the most important matter of the 
current financial statements based on professional judgment, and the key auditing matters are selected from the matters communicated between certified public accountants and managers." (Certified Public Accountants Auditing Standards No. 1504 - Communicating key audit matters in the audit report).

According to NO.1504, to determine the key audit matters, matters should be considered from three aspects: First, to assess major areas of the greater risk of material misstatement or special risk; Second, involving major areas of management judgment; Third, major transactions or matters. The auditor needs to state in the audit report that why the matter is the key audit matter and how the matter should be handled during the audit work. We collected audit reports through CSMAR database and manual collection, as of June 10, 2017, and found that a total of $84 \mathrm{~A}+\mathrm{H}$ shared listed company issued an audit report. In this paper, the audit reports of the key issues were summarized.

TABLE I. KAMS OF A+H SHARES LISTED COMPANIES IN 2016

\begin{tabular}{|c|c|c|}
\hline Type & Key Audit Matter & Total \\
\hline \multirow{5}{*}{$\begin{array}{c}\text { Revenue } \\
\text { Recognition }\end{array}$} & Revenue Recognition-Accuracy & 12 \\
\hline & Revenue Recognition-Cut-off & 2 \\
\hline & $\begin{array}{c}\text { Revenue Recognition- product sales } \\
\text { and construction contracts }\end{array}$ & 8 \\
\hline & Government subsidy & 2 \\
\hline & Deferred income & 2 \\
\hline \multirow[t]{5}{*}{$\begin{array}{c}\text { Fair Value } \\
\text { Measurements }\end{array}$} & $\begin{array}{c}\text { Fair value of consumptive biological } \\
\text { assets }\end{array}$ & 2 \\
\hline & Valuation of financial instruments & 12 \\
\hline & $\begin{array}{l}\text { Confirmation of termination of } \\
\text { financial assets }\end{array}$ & 1 \\
\hline & Identifiable intangible assets & 1 \\
\hline & Real estate investment & 1 \\
\hline \multirow[t]{11}{*}{$\begin{array}{l}\text { Impairment of } \\
\text { Assets }\end{array}$} & $\begin{array}{l}\text { Devaluation of fixed assets and } \\
\text { construction projects }\end{array}$ & 17 \\
\hline & Impairment of goodwill & 17 \\
\hline & Impairment of financial assets & 7 \\
\hline & $\begin{array}{l}\text { Preparation for fixed assets } \\
\text { impairment }\end{array}$ & 7 \\
\hline & $\begin{array}{l}\text { Preparation for bad debts of accounts } \\
\text { receivable }\end{array}$ & 16 \\
\hline & loss of loans and advances & 10 \\
\hline & $\begin{array}{l}\text { Allowance to reduce inventory to } \\
\text { market }\end{array}$ & 17 \\
\hline & Loss of contract loss & 1 \\
\hline & $\begin{array}{l}\text { Impairment of the intangible assets } \\
\text { of the franchise }\end{array}$ & 1 \\
\hline & $\begin{array}{l}\text { Devaluation of intangible assets with } \\
\text { uncertain life }\end{array}$ & 3 \\
\hline & Impairment of investment & 5 \\
\hline \multirow[t]{2}{*}{ Deferred Tax Assets } & $\begin{array}{c}\text { Deferred income tax assets } \\
\text { associated with a deductible loss }\end{array}$ & 5 \\
\hline & Deferred income tax & 1 \\
\hline Tax & $\begin{array}{l}\text { Change from tax business tax value- } \\
\text { to added tax or land value-added tax }\end{array}$ & 2 \\
\hline $\begin{array}{l}\text { Related Party } \\
\text { Transactions } \\
\end{array}$ & sale business & 2 \\
\hline Others & & 37 \\
\hline
\end{tabular}

The major factors that affect the audit are mainly the revenue recognition, fair value recognition, assets impairment, deferred income tax, equity transaction and other accounting matters. The disclosure of key audit matters has obvious features of industry concentration, such as financial industry generally focusing on the fair value of financial assets, impairment of financial assets, provision for loan and advances losses, and consolidation of structured entities. In addition, the auditors also proposed for their personality characteristics of key audit issues. For example, one of the key matters is litigation in BaiYunsan audit report, which is not disclosed in the other companies.

\section{B. Disclosure of Key Audit Matters: Problems and Improvements}

Through the analysis, we found that there are still some shortcomings for the disclosure of key audit matters in China. Firstly, the key audit matters are almost same. In particular, in some industries, only the data of matter is different. Second, the disclosure of information is redundant. For report users, an especially non-financial specialist, large sections of text is difficult to accurately understand.

The UK, which started the audit report reform early, has accumulated more than four years since 2012. The disclosure of key audit matters in UK is complete and reasonable [1]. By comparing with audit reports of public companies in the UK, I suggest that the standards for key auditing matters in China can make some improvements. First, use graphic form. Taking Roll Royce Holdings (PLC) as an example, in its annual audit report for 2015, KPMG, its audit firm, presented 18 key issues in the form of a scatter plot. Scatter plots can intuitively show the probability and impact of key audit issues. Through this form, users of audit reports can directly grasp the risk points and pay attention to their own concerns. Second, KPMG also provided a brief description of the audit work, detailing the contents of the audit work, such as asking, sampling of vouchers and so on. Chinese current guidelines did not require a clear indication of the details of the audit.

\section{COSTS AND BENEFITS OF KEY AUDIT MATTERS}

\section{A. Key audit matters and market reaction}

The economic consequences of key audit matters exist arguments. The first view is that when key audit matters are disclosed, the degree of information asymmetry between auditors and users of annual reports is reduced [9]. In this case, the key audit matter may be the appropriate solution to the needs of users. As long as key audit matters provide new information to users of annual reports, we may find that financial markets have responded to their disclosures. As a result, this paper proposes Hypothesis 1:

H1: Disclosure of key audit matters improve the market response compared to the company audit report that did not disclose key audit matters.

\section{B. Key audit matters and audit quality}

Disclosure of key audit matters can lead to higher audit quality. Disclosing some key audit issues may result in the auditors being held accountable for the key issues to be reported, and they will make further efforts to analyze these issues [8]. Some investors believe that the key audit matters 
can have a positive impact. Sun Lixia [5] suggests that we can expect "the quality competition among auditing firms, especially in the area of professional suspicion, will increase the value of auditing to investors." In addition, the benefits of disclosing these key issues have contributed to the audit report. This is even more noticeable to users, which may increase auditor costs if these audited key matters go wrong. Thus, this paper proposes Hypothesis 2:

H2: The disclosure of key audit matters improves the quality of auditing compared with the auditing report of the company that has not disclosed the key audit matters.

\section{EMPIRICAL MODEL}

\section{A. Samples and data sources}

The data used in this article, mainly from the CSMAR database and Resset database. At the same time, propensity score matching method was used to produce a comparable control group. The number of $\mathrm{A}+\mathrm{H}$ listed companies disclosing key audit matters is 84, while the number of comparable control group of A-share listed companies that did not disclose key audit matters is 154 .

\section{B. Empirical model}

We examined two models to understand benefits of China $\mathrm{A}+\mathrm{H}$ listed companies to disclose key audit matters: a model to evaluate their content (market reaction) and another model to assess the main characteristics of the audit: Quality (as measured by unexpected accrued profits). The KAM indicator variable is equal to 1 if the company's audit reports the key audit segment and 0 otherwise.

\section{Market Response Analysis}

The first model allows us to examine the reaction of financial markets when reporting the key auditing matters. Or to be more exact, we measure the cumulative abnormal return (CAR) around the announcement date.

$|\mathrm{CAR}|=\beta_{0}+\beta_{1}$ KAM $+\beta_{2}$ LN_MARKET_CAP $+\beta_{3}$ ILING DELAY $+\beta_{4} \mathrm{MB}+\beta_{5} \mathrm{DEBT}+\beta_{6} \mathrm{VAR}$ NI TA $+\beta_{7} \mathrm{ROA}+$ $\beta_{8}$ IFRS $+\beta_{9}$ CROSS_LIST + firm fixed effects + year fixed effects $+\varepsilon$

We use the absolute value of cumulative abnormal returns (|CAR $\mid)$ to cover the declaration date and the day after the declaration. If the disclosure of key audit matters reduces the asymmetry of information, the key auditing matters will disclose a positive coefficient of KAM. We control the firm size(LN_MARKET_CAP), delay in filing the annual report (FILING_DELAY), market-to-book ratio (MB), leverage (DEBT), variation in net income (VAR_NI_TA), return on assets (ROA), whether the company uses International Financial Reporting (IFRS), whether the company is crosslisted in the United States (CROSS_LIST), and company and year fixed-effects.

\section{Audit Quality Analysis}

The second model in this paper can assess the impact of key audit matters on audit quality. In the previous studies, the unexpected accruals were used as a measure of audit quality. We use the following model to examine the relationship between audit quality and audit of key matters.

$\mid$ UNACC $\mid=\alpha_{0}+\alpha_{1}$ KAM $+\alpha_{2}$ LOGASSETS $+\alpha_{3}$ DEBT + $\alpha_{4}$ ROA $+\alpha_{5}$ LOSS $+\alpha_{6}$ CROSS_LIST $+\alpha_{7}$ BIG $4+$ firm fixed effects + year fixed effects $+\varepsilon$

We use the absolute value of unexpected accruals (|UNACC|). These unexpected accruals are generated by the modified Jones model. If key audit matters have an impact on audit quality, we expect KAM to be negatively correlated with |UNACC|. We also control other variables such as LOGASSETS, DEBT, profitability (ROA and LOSS), and whether or not the Big Four audits (BIG4) based on previous findings [2].

\section{EMPIRICAL RESULTS}

\section{A. Market Reaction}

Table II (Panel A) shows descriptive statistics for test and dependent variables $(|\mathrm{CAR}|)$.

TABLE II. MARKET REACTION ASSOCIATED WITH KEY AUDIT MATTERS (KAMs)

\begin{tabular}{|c|c|c|c|c|c|}
\hline \multicolumn{6}{|c|}{ Panel A Descriptive statistics for test variables } \\
\hline & Total Sample & $\begin{array}{c}\text { No KAM } \\
(\mathrm{KAM}=0)\end{array}$ & $\begin{array}{c}\text { KAM } \\
(\mathrm{KAM}=1)\end{array}$ & & Test \\
\hline Variable & $\mathrm{N}=238$ & $\mathrm{~N}=154$ & $\mathrm{~N}=84$ & t value & $\mathrm{P}$ \\
\hline$|C A R|$ & 0.0156 & 0.0206 & 0.0145 & 4.71 & $<0.01$ \\
\hline
\end{tabular}

Panel B Regression results

\begin{tabular}{|c|c|c|c|c|c|c|}
\hline \multirow[b]{2}{*}{ Parameter } & \multicolumn{3}{|c|}{$\begin{array}{l}\text { Model 1b(KAM Period) } \\
\qquad \mathrm{N}=238\end{array}$} & \multicolumn{3}{|c|}{$\begin{array}{l}\text { Model 1a(Sample Period) } \\
\qquad \mathrm{N}=84\end{array}$} \\
\hline & Coef. & Std. Err & $\mathrm{P}$ & Coef. & Std. Err & $\mathrm{P}$ \\
\hline$K A M$ & 0.0088 & 0.0103 & 0.39 & & & \\
\hline FILING_DELAY & 0.0000 & 0.0000 & 0.34 & 0.0000 & 0.0000 & 0.48 \\
\hline МТОВ & 0.0004 & 0.0004 & 0.36 & -0.0004 & 0.0006 & 0.55 \\
\hline$D E B T$ & 0.0003 & 0.0006 & 0.59 & 0.0006 & 0.0007 & 0.45 \\
\hline$V A R \_N I \_T A$ & -0.0025 & 0.0185 & 0.89 & -0.0132 & 0.0193 & 0.49 \\
\hline$R O A$ & 0.0187 & 0.0213 & 0.38 & 0.0186 & 0.0237 & 0.43 \\
\hline IFRS & 0.0084 & 0.0048 & 0.08 & 0.0064 & 0.0045 & 0.15 \\
\hline$U S A$ & 0.0014 & 0.0027 & 0.61 & 0.0017 & 0.0030 & 0.57 \\
\hline Firm_Fixed Effects & incl. & & & incl. & & \\
\hline $\begin{array}{l}\text { Year Fixed Effects } \\
\text { F-Value }\end{array}$ & $\begin{array}{l}\text { Incl. } \\
2.27\end{array}$ & & & $\begin{array}{r}\text { Incl. } \\
2.130\end{array}$ & & \\
\hline Adj R-Sq & 0.255 & & $<.01$ & 0.283 & & \\
\hline
\end{tabular}

Contrary to expectations, univariate statistics show that the absolute CAR and KAM requirements are significantly lower. Panel B results show that the introduction of KAM has no significant effect on the financial markets. Therefore, we found no evidence that the value of the information provided in the Key Audit Matters section of the audit report was higher than the value of the other information and that there was no 
evidence that the key audit matters would eliminate the information asymmetry.

\section{B. Unanticipated Accrued Profit}

Panel A in Table III shows descriptive statistics for the dependent variable (|UNACC|). Contrary to expectation, the unanticipated accrued profits during the period of the disclosure of the key audit matters were higher than the control group and this difference was significant.

Panel B in Table III shows that the disclosure of key audit matters does not affect the level of non-estimated accrued profits and therefore there is no evidence that the quality of financial reporting will be improved upon disclosure of key audit matters.

TABLE III. UNEXPECTED ACCRUALS ASSOCIATION WITH JUSTIFICATION OF ASSESSMENTS

Panel A Descriptive statistics for test variables

\begin{tabular}{llllll}
\hline & Total Sample & $\begin{array}{l}\text { No KAM } \\
(\text { KAM }=0)\end{array}$ & $\begin{array}{l}\text { KAM } \\
(\text { KAM=1) }\end{array}$ & Test \\
\hline Variable & $\mathrm{N}=238$ & $\mathrm{~N}=154$ & $\mathrm{~N}=84$ & t value & $\mathrm{P}$ \\
|UNACC & 0.0719 & 0.0469 & 0.0736 & 1.94 & $<.10$ \\
\hline
\end{tabular}

Panel B Regression results

\begin{tabular}{lllllll}
\hline & \multicolumn{5}{c}{ Model 2b N=238 } & \multicolumn{3}{c}{ Model 2a N =84 } \\
\hline Variable & Coef. & Std. Err. & P & Coef. & Std. Err. P \\
KAM & -0.0251 & 0.0453 & 0.58 & & & \\
LOG_ASSETS & -0.0082 & 0.0569 & 0.70 & -0.0124 & 0.0787 & 0.63 \\
DEBT & -0.0396 & 0.0542 & 0.67 & -0.0932 & 0.0729 & 0.38 \\
ROA & -0.0313 & 0.0213 & 0.90 & 0.1558 & 0.0256 & 0.59 \\
LOSS & 0.0241 & 0.2614 & 0.37 & 0.0461 & 0.2921 & 0.13 \\
CROSS_LIST & -0.0264 & 0.0934 & 0.45 & -0.0215 & 0.1063 & 0.60 \\
BIG4 & -0.0755 & 0.0266 & 0.19 & -0.0706 & 0.0300 & 0.37 \\
Firm_Fixed Effects & Incl. & $<.01$ & Incl. & & \\
Year_Fixed Effects & Incl. & & $<.01$ & Incl. & & \\
\hline F-Value & 2.72 & & & 2.71 & & \\
Adj R-Sq & 0.475 & & & 0.493 & & \\
\hline
\end{tabular}

\section{SUMMARY}

This article describes content statistics; specifically analyzed the audit report of the $\mathrm{A}+\mathrm{H}$ share listed company. We found that the content of key audit matters in the auditing report were generally related to revenue recognition, fair value recognition, impairment of assets, deferred income tax and equity trading, etc. The disclosure of key audit matters is of an industrial nature and differentiation to a certain extent. However, compared with the UK audit report, the current disclosure of key audit issues in China remains to be improved. This paper argues Chinese auditors can improve the quality of KAMs disclosure by adding graphics, giving an opinion on every key matter, and disclosing the content of the audit on the key audit matters in details.

Furthermore, this study examines how the promulgation of new auditing standards - adding key audit matters, affects investors (market reaction) and the audit quality. We conclude that there are no obvious benefits. In fact, the market did not significantly react to the disclosure of key audit matters. Besides, the disclosure of key audit matters did not demonstrate a higher audit quality (measured by unexpected accrued profits).These findings show that the newly enacted guidelines in China for adding key auditing matters are not as informative as the regulators expected, nor do they significantly alter the audit quality. However, our studies allow enriching the current international debate on the introduction of key audit matters.

\section{REFERENCES}

[1] Chen Bo, "Experiences and Implications of the Audit Report Reform in the UK," Chinese Certified Public Accountants, vol.5, pp. 118-123, 2016.(In Chinese)

[2] Jiang Yao Ming, “Tang Yanjun. Certified Public Accountants, Human Capital, Access Rights and Audit Quality, ” Accounting Research, vol. 8, pp. 89-95, 2016.(In Chinese)

[3] Luo Chunhua and Yu Shulan, “Accounting for changes in the audit report changes, challenges and solutions, " Finance and Accounting, vol.6, pp. 69-71, 2017.(In Chinese)

[4] Kan Jinghua, "International Auditing and Assurance Standards Board audit report model changes and inspiration, ” Auditing and Economic Research, vol. 14(2), pp.58-66, 2017.(In Chinese)

[5] Sun Lixia, "Whether the comparability of accounting information can reduce the cost of auditors? " Chinese Certified Public Accountants, vol.4, pp. 64-68, 2016.(In Chinese)

[6] Xu Lei, "The latest revision of the audit report series of guidelines for analysis and interpretation, "New Accountants, vol.3, pp. 24-26, 2016.(In Chinese)

[7] Yang Jianrong, “Audit study of British state-owned enterprises, ” Auditing Research, vol.2, pp. 22-35, 2016. (In Chinese)

[8] Zhao Yanbing and Li Qingyuan, "Restatements of financial statements, product market competition and heterogeneous risks, " Auditing Research, vol.3, pp. 84-89, 2016. (In Chinese)

[9] Zhang Jixun, Cai Yandong and Liu Wenhuan, “ Improvement of Standard Audit Report, Relationship between Management and Auditors and Willingness of Managers to Communicate - An Experimental Evidence, ” Audit Research, vol.3, pp. 77-83,2016.(In Chinese) 